\title{
PENERAPAN EXTREME LEARNING MACHINE (ELM) UNTUK PERAMALAN LAJU INFLASI DI INDONESIA
}

\author{
Adyan Nur Alfiyatin ${ }^{1}$, Wayan Firdaus Mahmudy ${ }^{2}$, Candra Fajri Ananda ${ }^{3}$, Yusuf Priyo Anggodo ${ }^{4}$ \\ ${ }^{1,2}$ Fakultas Ilmu Komputer, Universitas Brawijaya Malang, ${ }^{3}$ Fakultas Ekonomi dan Bisnis, Universitas \\ Brawijaya Malang, ${ }^{4}$ Data Analyst, Ilmuone Data, Jakarta Indonesia \\ Email: ${ }^{1}$ adyannur.alfiyatin@gmail.com, ${ }^{2}$ wayanfm@ub.ac.id, ${ }^{3}$ cfajri@ub.ac.id, ${ }^{4}$ anggodoyusuf1950@ gmail.com
}

(Naskah masuk: 03 Juli 2018, diterima untuk diterbitkan: 20 Desember 2018)

\begin{abstract}
Abstrak
Inflasi merupakan salah satu indikator untuk mengukur perkembangan suatu bangsa. Apabila inflasi tidak terkontrol akan memberikan banyak dampak negative terhadap masyarakat disuatu negara. Ada banyak cara untuk mengendalikan inflasi, salah satunya dengan peramalan. Peramalan adalah suatu aktivitas untuk mengetahui kejadian di masa mendatang berdasarkan data masa lalu. Pada penelitian ini menggunakan metode kecerdasan buatan yakni extreme learning machine (ELM). Kelebihan ELM yaitu cepat dalam proses pembelajaran. Berdasarkan penggujian yang dilakukan metode ELM mendapatkan nilai kesalahan sebesar 0.0202008 , lebih kecil dibandingkan dengan metode backpropagation sebesar 1.16035821. Hal tersebut membuktikan bahwa metode ELM sangat cocok digunakan untuk peramalan.
\end{abstract}

Kata kunci: inflasi, extreme learning machine, backpropagation, jaringan syaraf tiruan.

\section{IMPLEMENTATION EXTREME LEARNING MACHINE FOR INFLATION FORECASTING IN INDONESIA}

\begin{abstract}
Inflation is one indicator to measure the development of a nation. If inflation is not controlled will give many negative impacts to the people in a country. There are many ways to control inflation, one with forecasting. Forecasting is an activity to know future events based on past data. In this research using artificial intelligence method is extreme learning machine (ELM). The advantages of ELM are fast in the learning process. Based on ELM testing gets obtained an error value of 0.0202008, smaller than the backpropagation method of 1.16035821. It proves that ELM method is very suitable for forecasting.
\end{abstract}

Keywords: inflation, extreme learning machine, backpropagation, neural network.

\section{PENDAHULUAN}

Inflasi merupakan salah satu indikator untuk mengukur perkembangan suatu bangsa. Inflasi adalah gejala ekonomi yang berupa meningkatnya harga secara terus menerus dan mempengaruhi harga-harga lainnya (Ascari dan Sbordone, 2014). Berbagai permasalahan timbul apabila laju inflasi mengalami kenaikan secara berkelanjutan seperti perekonomian yang tidak stabil, pertumbuhan ekonomi lambat, penurunan nilai mata uang yang secara tidak langsung mempengaruhi aktivitas perdagangan global (Charnavoki dan Dolado, 2017). Secara global, kenaikan inflasi akan berdampak pada nilai jual barang dan jasa, biaya kebutuhan seharihari semakin tinggi. Pemerintah dapat melakukan antisipasi untuk pengendalian dampak inflasi dengan melakukan peramalan.
Untuk mengendalikan laju inflasi diperlukan sebuah sistem peramalan, yang berfungsi memberikan informasi kepada pemerintah untuk mengantisipasi kenaikan laju inflasi pada masa mendatang. Selain itu hasil dari peramalan dapat digunakan untuk masyarakat luas seperti para investor untuk mengetahui informasi investasi sebagai peningkatan investasi mereka sehingga investor mendapatkan keuntungan yang maksimal. Dapat dimanfaatkan oleh para petani untuk menaikkan harga komoditi sehingga para petani mendapatkan hasil penjualan pertanian yang besar (Sari dkk., 2017).

Peramalan laju inflasi dapat dilakukan berdasarkan data historis menggunakan teknik analisis time series, dan penambahan beberapa faktor eksternal yang mempengaruhi peramalan laju inflasi. Penelitian yang telah dilakukan oleh Sari, Mahmudy dan Wibawa (2017), Anggodo dan 
Cholissodin (2017) menggunakan faktor eksternal yang meliputi Indeks Harga Konsumen (IHK), tingkat suku bunga, jumlah uang beredar, nilai tukar rupiah. Pada penelitian tersebut, ada factor lain yang mempengaruhi tingkat laju inflasi yang belum dijadikan sebagai parameter tambahan yakni nilai kredit dan nilai asset. Kedua parameter tersebut memberikan pengaruh sangat signifikan terhadap laju inflasi seperti pertumbuhan nilai kredit yang berlebihan akan memicu pertumbuhan permintaan aggregate diatas penawaran sehingga akan mengakibatkan peningkatan inflasi (Utari, Arimurti dan Kurniati, 2012), nilai asset akan berpengaruh terhadap tingkat inflasi, inflasi tinggi maka nilai asset juga tinggi, dengan demikian sektor perbankan mempunyai peran penting dalam pertumbuhan ekonomi. Berdasarkan efek yang ditimbulkan sehingga pada penelitian ini akan menambahkan parameter nilai kredit dan nilai asset untuk peramalan laju inflasi di Indonesia. Dengan ditambahnya parameter tersebut diharapkan akan meningkatkan hasil peramalan yang lebih akurat.

Peramalan dapat dilakukan dengan berbagai macam metode diantaranya neural network dengan metode pembelajaran backpropagation (Sari, Mahmudy \& Wibawa 2016; Sari, Mahmudy \& Wibawa 2017), support vector regression (SVR) (Zhang dan Li, 2012), extreme learning machine (ELM) (Huang, Song dan You., 2015). Berdasarkan penelitian terdahulu yang menunjukkan bahwa metode ELM mendapatkan nilai kesalahan yang kecil dan komputasi cepat daripada metode backpropagation. Sehingga penelitian ini mengusulkan peramalan laju inflasi di Indonesia menggunakan metode ELM. Diharapkan dengan penerapan ELM mendapatkan hasil peramalan yang efektif.

ELM adalah metode yang bekerja dengan konsep single hidden layer feed forward networks (SLFNs), metode ini diciptakan untuk mengatasi kelemahan metode jaringan syaraf tiruan feedforward lebih-lebih pada proses learning speed. ELM baik digunakan untuk mengatasi masalah peramalan dengan waktu pelatihan cepat, mudah untuk diaplikasikan pada masalah kompleks dan diterapkan pada kehidupan nyata (Huang et al. 2006). Berdasarkan kelebihan yang dimiliki oleh ELM sehingga fokus penelitian ini adalah mengukur performa kecepatan waktu komputasi dan seberapa akurat hasil yang didapatkan pada metode ELM. Nilai keakuratan akan dihitung dengan menggunakan Root Mean Square Error (RMSE).

\section{PENELITIAN TERKAIT}

Pada beberapa penelitian sebelumnya telah dilakukan peramalan laju inflasi. Ada beberapa metode yang dapat diterapkan untuk peramalan laju inflasi yaitu metode dalam kelompok machine learning, data mining seperti support vector machine (SVM) (Sheta, Ahmed dan Faris. 2015), support vector regression (SVR) (Zhang dan Li, 2012). Sheta, Ahmed dan Faris (2015) melakukan peramalan dengan tujuan dapat membantu pengambilan keputusan untuk tindakan yang benar pada pengembangan ekonomi yang lebih baik. Dengan menggunakan metode SVM mendapatkan nilai error yang relative tinggi, sehingga metode ini belum dapat diterapkan. Zhang dan Li (2012) telah berhasil mendapatkan hasil peramalan lebih baik dengan Support Vector Regression (SVR), penelitian yang dilakukan dengan dua parameter yaitu Customer Price Index (CPI) dan money gap. Tujuan penelitian fokus terhadap performa metode SVR dan hasil diperoleh dengan membandingan metode SVR, backpropagation dan regresi linear. Dengan metode SVR pada pemilihan parameter menggunakan cara manual dan terkadang pemilihan fungsi kernel tidak tepat.

Beberapa penelitian lain menerapkan metode dalam kelompok artificial neural network antara lain extreme learning machine (ELM) (Tiwari dan Adamowski. 2016) backpropagation (Sari, Mahmudy dan Wibawa. 2016), multilayer feedforward neural network (Chavez-Hurtado \& Cortes-Fregoso 2013). Tiwari dan Adamowski (2016) menggunakan ELM pada peramalan permintaan air dan hasil yang diperoleh membuktikan bahwa ELM performanya lebih unggul daripada metode artificial neural network (ANN). Dengan adanya penelitian ini memberikan kesempatan untuk mengeksplorasi teknik ELM dalam peramalan. Dikarenakan kesalahan prediksi jauh lebih kecil dan waktu eksekusi model lebih pendek dibandingan model pembelajaran lain. Sari, Mahmudy dan Wibawa (2016) melakukan peramalan dengan menggunakan data time series laju inflasi dan factor eksternal yang mempengaruhi yaitu CPI. Pada penelitiannya menunjukkan bahwa backpropagation memperoleh hasil yang lebih baik dari pada menggunakan fuzzy inference system (FIS) sugeno. Analisis performa antara kedua metode menggunakan root mean square error (RMSE). Chavez, Hurtado \& Cortes-Fregoso (2013) melakukan peramalan dengan menggunakan data time series laju inflasi dan menghasilkan 3 kategori inflasi yaitu volatile inflation phase, transition phase, stability phase. Dengan beberapa penelitian terdahulu menunjukkan bahwa metode neural network bagus dalam hal peramalan. Sehingga penelitian ini mengusulkan penerapan neural network dengan metode ELM pada peramalan laju inflasi yang melengkapi kekurangan pada penelitian Sari, Mahmudy dan Wibawa, (2017), Anggodo dan Cholissodin (2017) dengan ditambahkan faktor yang mempengaruhi tingkat laju inflasi. Penelitian ini mengusulkan penambahan faktor eksternal yang mempengaruhi laju inflasi diantaranya IHK (Indeks Harga Konsumen), tingkat suku bunga, jumlah uang beredar, nilai tukar rupiah, nilai kredit dan nilai asset 
dengan tujuan untuk mengetahui performa metode yang dipakai dalam mengatasi masalah tersebut.

\section{DATA SET}

Data yang digunakan pada penelitian ini diperoleh dari Bank Indonesia (Indonesia 2017) dan Badan Pusat Statistik (BPS). Rekaman data yang digunakan mulai Januari 2005 - Desember 2017. Parameter yang digunakan adalah data historis dengan analisis deret waktu (b-1, b-2, b-3). b-1 mewakili parameter bulan sebelumnya, b-2 mewakili 2 bulan sebelumnya, dan b-3 mewakili tiga bulan sebelumnya. Penelitian ini juga menggunakan beberapa factor eksternal yang mempengaruhi tingkat inflasi yaitu IHK, tingkat suku bunga, jumlah uang beredar, nilai tukar rupiah, nilai kredit dan nilai aset. Parameter tersebut dijadikan sebagai variabel input pada peramalan laju inflasi sedangkan variabel output berupa hasil peramalan tingkat inflasi di Indonesia.

\section{PERAMALAN MENGGUNAKAN BACKPROPAGATION}

Menurut Hill, Connor dan Remus (1996) backpropagation baik digunakan untuk peramalan menggunakan data time series. Selain itu, backpropagation kinerjanya sederhana dan hasil yang didapatkan lebih akurat di bandingkan metode statistic lainnya (Werbos 1990). Didalam backpropagation terdiri dari dua proses yaitu feed forward dan back propagation error. Langkah pada metode backpropagation, sebagai berikut :

Langkah 1 : Inisialisasi bobot secara random.

Langkah 2 : Kerjakan langkah 3 sampai 9, apabila syarat berhenti adalah salah.

Langkah 3 : Kerjakan langkah 4 sampai 8 untuk setiap pasangan pelatihan.

\section{Perambatan Maju}

Langkah 3 : Untuk setiap unit masukan (xi , i = 1, 2, ....., n) menerima isyarat masukan xi dan diteruskan ke unit-unit tersembunyi.

Langkah 4 : Untuk setiap unit tersembunyi (zj, j = $1,2, \ldots . .$, p) menjumlahkan isyarat masukan terbobot.

$$
z_{-} i n_{j}=V_{o j}+\sum_{i=1}^{n} x_{i} v_{i j}
$$

Dengan menerapkan fungsi aktivasi hitung menggunakan fungsi sigmoid :

$Z_{j}=\frac{1}{1+E X P^{-Z_{-} i n j}}$

Dan kirim isyarat ini ke unit-unit keluaran.

Langkah 5 : untuk setiap keluaran (yi, $\mathrm{i}=1, \ldots ., \mathrm{m}$ ) dijumlahkan dengan masukan factor berbobot,

$$
y_{\_} i n_{k}=w_{o k}+\sum_{j=1}^{v} z_{j} w_{j k}
$$

Dengan menerapkan fungsi aktivasi hitung dengan fungsi sigmoid,
$y_{k}=\frac{1}{1+E X P^{-y_{-} \text {ink }}}$

\section{Perambatan Mundur}

Langkah 6 : untuk setiap unit keluaran $(\mathrm{yk}, \mathrm{k}=1$, ..., m) menerima pola sasaran berkaitan dengan pola pelatihan masukannya. Hitung galat informasi :

$E_{k}=\left(t_{k}-y_{k}\right) y_{k}$

Hitung koreksi bobot dan prasikapnya:

$\Delta w_{j k}=\alpha \delta_{k}$

Langkah 7: untuk setiap unit tersembunyi (zj, j = 1, ..., p ) menjumlahkan delta masukannya (dari unitunit di lapisan atasnya ).

$$
\delta_{-} i_{j}=\sum_{k=1}^{m} \delta_{k} w_{j k}
$$

Kemudian, dikalikan dengan turunan fungsi aktivasi untuk menghitung kesalahan

$\delta_{j}=\delta_{-} i n_{j}\left(Y_{i n j}\right)$

Hitung koreksi bobot factor penimbang untuk memperbaiki bobot:

$\Delta w_{i j}=\alpha \delta_{j}$

Perbaharui bobot dan prasikap.

Langkah 8 : untuk setiap unit keluaran ( $\mathrm{yk}, \mathrm{k}=1$, ..., $\mathrm{m}$ ) memperbaharui bobot-bobot dan prasikapnya $(\mathrm{j}=0,1, \ldots . \mathrm{p})$

$w_{j k}($ baru $)=w_{j k}(\operatorname{lama})+\Delta w_{j k}$

Tiap unit tersembunyi $(\mathrm{zj}, \mathrm{j}=1, \ldots, \mathrm{p})$ memperbaharui bobot-bobot dan prasikapnya $(\mathrm{i}=0$, $1, \ldots, n)$

$v_{i j}($ baru $)=v_{i j}(\operatorname{lama})+\Delta v_{i j}$

Langkah 9 : Uji syarat berhenti

Prosedur pembaharuan bobot-bobot dapat dimodifikasi dengan menggunakan momentum. Dengan menambahkan momentum ke dalam rumus pembaharuan bobot, biasanya konvergensi akan lebih cepat dicapai. Dalam pembaharuan bobot menggunakan momentum, nilai bobot pada iterasi ke $(\mathrm{t}+1)$ ditentukan oleh nilai bobot pada iterasi ke $-\mathrm{t}$ dan ke (t-1). Adapun rumus pembaharuan bobotnya, sebagai berikut :

$w_{j k}(t+1)=w_{j k}(t)+a \delta_{k} z_{j}+\mu\left[w_{j k}(t)-w_{j k}(t-1)\right]$

Atau

$\Delta w_{j k}(t+1)=a \delta_{k} z_{j}+\mu \Delta w_{j k}(t)$

Dan

$v_{i j}(t+1)=v_{i j}(t)+a \delta_{j} x_{i}+\mu\left[w_{j k}(t)-w_{j k}(t-1)\right]$ 
Atau

$\Delta v_{i j}(t+1)=a \delta_{j} x_{i}+\mu \Delta v_{i j}(t)$

Dengan:

$\mathrm{X}_{\mathrm{i}} \ldots . \mathrm{X}_{\mathrm{n}}$ : Masukan

$\mathrm{y}_{\mathrm{i}} \ldots \mathrm{y}_{\mathrm{n}}$ : Keluaran

$\mathrm{Z}_{\mathrm{i}} \ldots \mathrm{Z}_{\mathrm{n}}$ : Nilai lapisan tersembunyi

$\mathrm{v}_{\mathrm{ij}}$ : bobot antara lapisan masukan dan lapisan

tersembunyi

$\mathrm{W}_{\mathrm{jk}}$ : bobot antara lapisan tersembunyi dan lapisan

keluaran

$\delta$ : Galat informasi

a : Konstanta berkelanjutan

\section{PERAMALAN MENGGUNAKAN EXTREME LEARNING MACHINE (ELM)}

Metode ini dikenalkan oleh Huang, dkk (2004). ELM merupakan jaringan syaraf tiruan feed forward yang menggunakan konsep Single Hidden Layer Feedforward Neural Networks (SLFNs), dikarenakan ELM hanya mempunyai satu hidden layer pada arsitektur jaringannya. ELM dibuat untuk mengatasi kelemahan dari jaringan syaraf tiruan sebelumnya dalam proses learning speed. Dengan pemilihan parameter-parameter seperti input, weight dan hidden bias secara random sehingga kinerja dari learning speed pada ELM ini lebih cepat, mampu menghasilkan good generalization performance tanpa ada masalah overtraining. Penggunaan ELM dimaksudkan untuk mengantisipasi adanya data yang setiap bulan bertambah dan penambahan faktor eksternal yang dibutuhkan untuk mendapatkan hasil peramalan akurat. Tahapan - tahapan pada metode ELM, sebagai berikut :

\section{Normalisasi Data}

Normalisasi data merupakan suatu proses perubahan bentuk data menjadi nilai yang lebih spesifik dalam batas nilai 0-1. Bertujuan untuk menyesuaikan data masukan terhadap data keluaran. Cara normalisasi yang digunakan adalah data asli setiap parameter dibagi dengan nilai maksimal dari masing-masing parameter. Pada persamaan 16 menunjukkan normalisasi data :

$v^{\prime}=\frac{v}{\max }$

Keterangan :

$\mathrm{v}$ ' = nilai baru

$\mathrm{v}=$ data asli

$\max =$ data maksimal dari setiap parameter.

\section{Proses Training}

Merupakan suatu proses yang bertujuan untuk melakukan pelatihan dengan menggunakan data latih. Dengan pelatihan ini akan mendapatkan nilai bobot yang optimal. Tahapan pada proses training, sebagai berikut (Sugianto et al. 2018):

a. Membuat nilai secara acak untuk matrik $\mathrm{W}_{\mathrm{mn}}$ sebagai bobot masukan dengan range $[0,1]$, dalam bentuk array ukuran $\mathrm{m}$ (jumlah hidden neuron) x n (jumlah input neuron). Kemudian buat nilai acak lagi untuk matriks bias $b$ dengan range [0,1] dalam ukuran $1 \mathrm{x}$ (jumlah hidden neuron).

b. Menghitung nilai matriks keluaran hidden layer dengan persamaan 17. Perhitungan b (ones $\left(\mathrm{i}_{\text {train }}, 1\right)$,) memperbanyak matriks biar sebanyak jumlah data latih.

$$
H=\frac{1}{1+\exp \left(-\left(x_{\text {train }} w^{T}+b\left(\text { ones }\left(i_{\text {train }}, 1\right), ;\right)\right)\right)}
$$

Keterangan:

$$
\begin{aligned}
& H \quad=\text { matriks keluaran hidden layer } \\
& \begin{array}{ll}
\mathrm{x}_{\text {train }} & =\text { matriks input pada data latih yang telah } \\
\text { dinormalisasi }
\end{array} \\
& \begin{array}{ll}
\mathrm{W}^{\mathrm{T}} & =\text { matriks transpose dari bobot } \\
\mathrm{i}_{\text {train }} & =\text { jumlah data latih } \\
\mathrm{b} & =\text { matriks bias }
\end{array}
\end{aligned}
$$

c. Menghitung $\beta$ sebagai bobot keluaran dengan menggunakan persamaan 18 dimana $\mathrm{H}^{+}$atau matriks Moore-Penrose Pseudo Invers dapat dihitung dengan persamaan 19.

$$
\begin{array}{ll}
\beta & =H^{+} t \\
H^{+} & =\left(\mathrm{H}^{\mathrm{T}} \mathrm{H}\right)^{-1} \mathrm{H}^{\mathrm{T}}
\end{array}
$$

keterangan:

$\beta=$ matriks bobot keluaran

$\mathrm{H}^{+} \quad=$ matriks moore-penrose pseudo invers dari matriks $\mathrm{H}$.

$t \quad=$ matriks target

$H \quad=$ matriks keluaran hidden layer

d. Menghitung hasil keluaran dengan menggunakan persamaan 20 .

$$
\mathrm{Y}=\mathrm{H} \beta
$$

Keterangan:

$$
\begin{array}{ll}
\mathrm{Y} & =\text { hasil prediksi } \\
\mathrm{H} & =\text { matriks keluaran hidden layer } \\
\beta & =\text { matriks bobot keluaran }
\end{array}
$$

Pada proses training penelitian ini tahapan yang digunakan sesuai dengan alur dari proses dikarenakan focus penelitian ini adalah mengetahui performa metode yang dipakai dan mengetahui dengan adanya penambahan variabel (faktor eksternal) yang digunakan mampu menghasilkan peramalan yang akurat.

\section{Proses Testing}

Setelah melakukan proses training, kemudian dilakukanlah proses testing dengan menggunakan data uji. Proses testing ini bertujuan untuk melakukan uji coba hasil training, sehingga dapat diketahui akurasi dari program. Tahapan-tahapan 
yang dilakukan, sebagai berikut (Sugianto et al. 2018):

a. Mengetahui nilai $\mathrm{W}_{\mathrm{mn}}, \mathrm{b}$ dan $\beta$ dari proses training.

b. Menghitung nilai matriks keluaran pada hidden layer menggunakan persamaan 21. Perhitungan b (ones $\left(\mathrm{i}_{\text {train }}, 1\right)$,) untuk memperbanyak matriks bias sebanyak jumlah data uji.

$H=\frac{1}{1+\exp \left(-\left(x_{\text {test }} w^{T}+b\left(\text { ones }\left(i_{\text {test }}, 1\right), ;\right)\right)\right)}$

Keterangan:

$H \quad=$ matriks keluaran hidden layer

$\mathrm{x}_{\text {test }}=$ matriks input pada data uji yang telah dinormalisasi

$\mathrm{w}^{\mathrm{T}} \quad=$ matriks transpose dari bobot

$\mathrm{i}_{\text {test }} \quad=$ jumlah data uji

$\mathrm{b} \quad=$ matriks bias

c. Menghitung hasil keluaran dengan menggunakan persamaan 20 .

d. Denormalisasi hasil prediksi menggunakan persamaan 23.

e. Menghitung nilai evaluasi menggunakan persamaan 22 .

$R M S E=\sqrt{\sum_{i=1}^{n} \frac{\left(\text { data aktual }_{i}\right)-\left(\text { data peramalan }_{i}\right)^{2}}{n}}$

$$
\begin{array}{ll}
n & =\text { jumlah seluruh data } \\
i & =\text { data } \mathrm{ke}-i \\
\text { data aktual } & =\text { data sekarang } \\
\text { data peramalan } & =\text { data hasil peramalan }
\end{array}
$$

4. Denormalisasi Data

Proses ini berfungsi untuk mengembalikan nilai yang telah dinormalisasi menjadi nilai asli. Persamaan 22 mununjukkan proses denormalisasi data:

$v=\frac{\left(v^{\prime}-N e w_{-} \min A\right)}{\left(N e w_{-} \max A\right)(\max A-\min \mathrm{A})}+\min A$

$v^{\prime} \quad=$ data hasil normalisasi

$v \quad=$ hasil denormalisasi

$\max A=$ nilai maksimum dari seluruh data pada setiap variabel

$\min A=$ nilai minimum dari seluruh data pada setiap variable

$N e w_{-} \max A=$ nilai batas maksimum dalam pemetaan

New_min $A=$ nilai batas minimum dalam pemetaan $\mathrm{r}$.

Untuk peramalan laju inflasi menggunakan ELM, data yang digunakan dibagi menjadi 2 bagian yaitu data latih dan data uji. Pada penelitian sebelumnya seperti yang dilakukan oleh Sari dkk. (2016); Nafi'iyah (2016) perbandingan antara data latih dan data uji sebesar 70:20 dari keseluruhan data. Dengan perbandingan tersebut mendapatkan hasil optimal. Sehingga pada penelitian ini juga akan menggunakan $70 \%$ untuk data latih dan $20 \%$ untuk data uji.

\section{HASIL DAN ANALISIS}

Pada peramalan laju inflasi menggunakan extreme learning machine (ELM) dilakukan pengujian parameter terhadap jumlah neuron pada hidden layer. Pengujian ini bertujuan untuk mengetahui jumlah neuron yang optimal untuk melakukan peramalan laju inflasi. Pada pengujian ini dilakukan 10 kali percobaan dengan kelipatan 2 sesuai dengan penelitian yang telah di lakukan oleh Hidayat \& Suprapto (2012). Gambar 1. menunjukkan grafik hasil pengujian jumlah neuron.

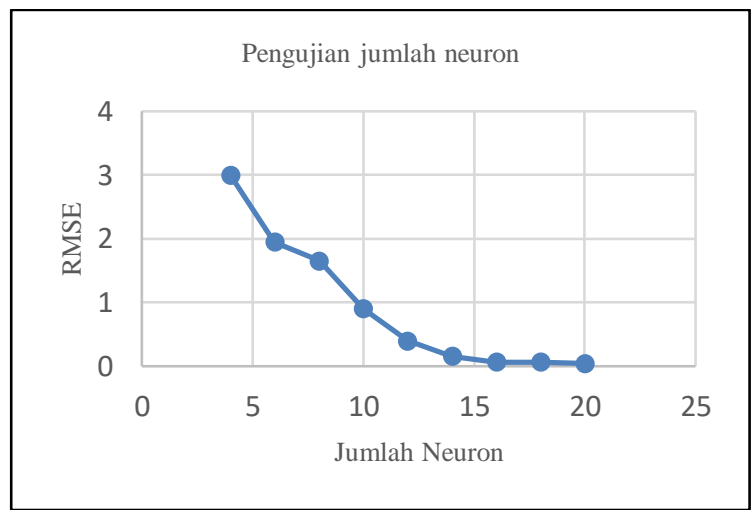

Gambar 1. Grafik pengujian jumlah neuron

Berdasarkan Gambar 1 nilai kesalahan terkecil terdapat pada jumlah neuron 20. Sehingga untuk proses testing akan menggunakan arsitektur 3 layer yaitu 1 layer input dengan 9 neuron, 1 layer hidden dengan 20 neuron dan 1 layer output dengan 1 neuron. Berdasarkan arsitektur tersebut, sehingga data yang diperoleh di tunjukkan pada Tabel 1.

Tabel 1 Perbandingan Data Aktual \& Data Prediksi

\begin{tabular}{cccc}
\hline Bulan & Aktual & Result & RMSE \\
\hline Jan-05 & 7.32 & 7.15 & 0.0272218 \\
Feb-05 & 7.15 & 6.93 & 0.0352282 \\
Mar-05 & 8.81 & 8.79 & 0.0032026 \\
Apr-05 & 8.12 & 8.05 & 0.011209 \\
May-05 & 7.4 & 7.34 & 0.0096077 \\
Jun-05 & 7.42 & 7.52 & 0.0160128 \\
Jul-05 & 7.84 & 8.55 & 0.113691 \\
Aug-05 & 8.33 & 8.02 & 0.0496397 \\
Sep-05 & 9.06 & 9.08 & 0.0032026 \\
Oct-05 & 17.89 & 17.95 & 0.0096077 \\
Nov-05 & 18.38 & 18.1 & 0.0448359 \\
Dec-05 & 17.11 & 17.2 & 0.0144115 \\
\hline Jan-06 & 17.03 & 17.05 & 0.0032026 \\
Feb-06 & 17.92 & 17.61 & 0.0496397 \\
Mar-06 & 15.74 & 15.67 & 0.011209
\end{tabular}


184 Jurnal Teknologi Informasi dan Ilmu Komputer (JTIIK), Vol. 6, No. 2, April 2019, hlm. 179-186

\begin{tabular}{cccc}
\hline Bulan & Aktual & Result & RMSE \\
\hline Apr-06 & 15.4 & 15.31 & 0.0144115 \\
May-06 & 15.6 & 15.68 & 0.0128103 \\
Jun-06 & 15.53 & 15.7 & 0.0272218 \\
Jul-06 & 15.15 & 15.69 & 0.0864692 \\
Aug-06 & 14.9 & 14.73 & 0.0272218 \\
Sep-06 & 14.55 & 14.47 & 0.0128103 \\
Oct-06 & 6.29 & 6.2 & 0.0144115 \\
Nov-06 & 5.27 & 5.13 & 0.0224179 \\
Dec-06 & 6.6 & 6.73 & 0.0208167 \\
\hline Jan-07 & 6.26 & 6.29 & 0.0048038 \\
Feb-07 & 6.3 & 6.37 & 0.011209 \\
Mar-07 & 6.52 & 6.62 & 0.0160128 \\
Apr-07 & 6.29 & 6.39 & 0.0160128 \\
May-07 & 6.01 & 6.07 & 0.0096077 \\
& & & \\
\hline
\end{tabular}

\begin{tabular}{cccc}
\hline Bulan & Aktual & Result & RMSE \\
\hline Jun-07 & 5.77 & 5.81 & 0.0064051 \\
Jul-07 & 6.06 & 6.06 & 0 \\
Aug-07 & 6.51 & 6.49 & 0.0032026 \\
Sep-07 & 6.95 & 7 & 0.0080064 \\
Oct-07 & 6.88 & 6.82 & 0.0096077 \\
Nov-07 & 6.71 & 6.53 & 0.0288231 \\
Dec-07 & 6.59 & 6.6 & 0.0016013 \\
Jan-08 & 7.36 & 7.23 & 0.0208167 \\
Feb-08 & 7.4 & 7.43 & 0.0048038 \\
Mar-08 & 8.17 & 8.21 & 0.0064051 \\
\hline & & & $\mathbf{0 . 0 2 0 2 0 0 8}$ \\
\hline
\end{tabular}

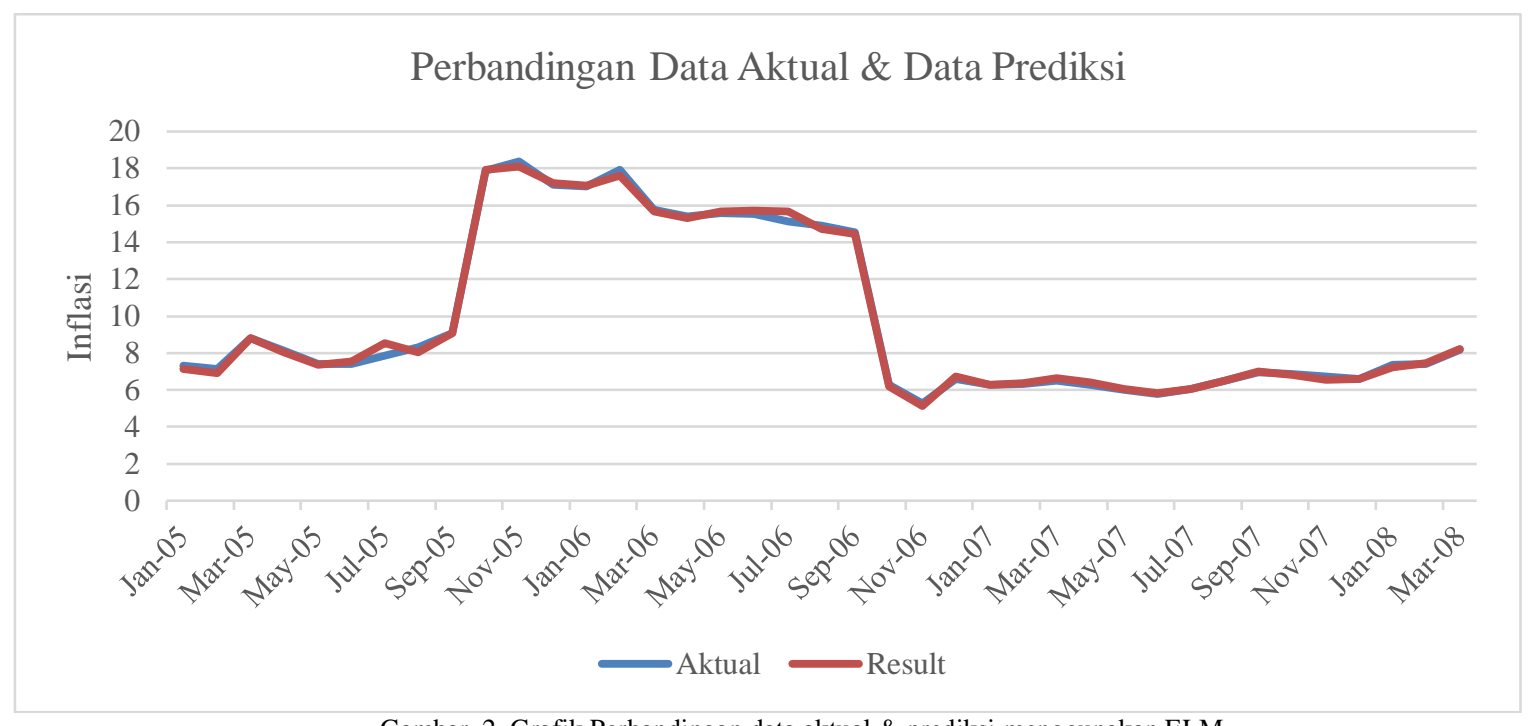

Gambar 2. Grafik Perbandingan data aktual \& prediksi menggunakan ELM

Tabel 1 dan Gambar 2. menunjukkan bahwa dengan metode extreme learning machine nilai error tertinggi hanya terjadi pada bulan juli 2005 yaitu 0.113691. Hal tersebut membuktikan bahwa metode extreme learning machine efektif digunakan untuk peramalan karena selisih antara data aktual dan data prediksi hanya 0.0202008 . Beberapa penelitian juga menegaskan bahwa nilai kesalahan ELM untuk peramalan relatif kecil dan waktu yang dibutuhkan untuk pelatihan cukup singkat (Handika, Giriantari \& Dharma. 2016; Hidayat \& Suprapto 2012). Pada Tabel 2 di tunjukkan hasil perbandingan metode ELM dan backpropagation. Berdasarkan Tabel 2 ELM hanya membutuhkan waktu 0 detik untuk mendapatkan nilai kesalahan sebesar 0.0202008 .

Tabel 2 Perbandingan ELM \& Backpropagation

\begin{tabular}{lllll}
\hline Metode & Neuron & Iterasi & RMSE & Waktu \\
\hline ELM & 20 & 1 & 0.0202008 & 0 detik \\
Backpro & 70 & 900 & 1.16035821 & 5 detik \\
\hline
\end{tabular}

\section{KESIMPULAN}

Berbagai isu terkait peramalan laju inflasi di Indonesia telah dibahas pada penelitian ini. Metode yang diusulkan mendapatkan nilai peramalan yang lebih baik daripada metode backpropagation yaitu sebesar 0.0202008. Pengujian yang dilakukan yaitu pengujian jumlah neuron pada hidden layer, hal tersebut bertujuan untuk mengetahui seberapa banyak neuron yang diperlukan untuk mendapatkan hasil yang optimal. Berdasarkan pengujian tersebut didapatkan bahwa arsitektur yang sesuai untuk peramalan laju inflasi dengan menggunakan 9 parameter uji adalah dengan 3 layer yaitu 1 layer input yang terdiri dari 9 neuron, 1 layer hidden dengan neuron sejumlah 20 neuron dan 1 layer output dengan 1 neuron. Fungsi aktivasi yang digunakan adalah fungsi sigmoid karena menyesuaikan range data 0-1. 
Penelitian ini menegaskan bahwa ELM mempunyai keunggulan pada cepatnya waktu komputasi di proses pelatihan, performa ELM tidak berkurang meskipun ada penambahan variabel yang digunakan, selain kelebihan, ELM juga mempunyai kekurangan yaitu pada proses penentuan jumlah neuron di hidden layer yang menggunakan proses trial dan error.

Untuk penelitian selanjutnya akan dilakukan proses penentuan jumlah neuron di hidden layer secara otomatis menggunakan metode optimasi dengan tujuan untuk membuat kinerja ELM lebih efektif dan efisien.

\section{DAFTAR PUSTAKA}

ANGGODO, Y.P. \& CHOLISSODIN, I., 2017. Improve Interval Optimization of FLR using Auto-Speed Acceleration Algorithm. Telecomunication, Computing Electronics and Control (TEKOMNIKA), 16(1), pp.1-12.

ASCARI, G. \& SBORDONE, A.M., 2014. The Macroeconomics of Trend Inflation. Journal of Economic Literature, 52(January 2012), pp.679-739. Available at: https://www.aeaweb.org/articles.php?doi=10.1 257/jel.52.3.679.

CHARNAVOKI, B.V. \& DOLADO, J.J., 2017. American Economic Association The Effects of Global Shocks on Small CommodityExporting Economies: Lessons from Canada Author ( $\mathrm{s}$ ): Valery Charnavoki and Juan J . Dolado Published by: American Economic Association Stable URL : http://www.jstor.org/stab. , 6(2).

CHAVEZ-HURTADO, J.L. \& CORTESFREGOSO, J.H., 2013. Forecasting Mexican inflation using neural networks. 23rd International Conference on Electronics, Communications and Computing, CONIELECOMP 2013, pp.32-35.

HANDIKA, I.P.S., GIRIANTARI, I.A. \& DHARMA, A., 2016. Perbandingan Metode Extreme Learning Machine dan Particle Swarm Optimization Extreme Learning Machine untuk Peramalan Jumlah Penjualan Barang. Teknologi Elektro, 15(1), pp.84-90.

HIDAYAT, R. \& SUPRAPTO, 2012. Meminimalisasi Nilai Error Peramalan dengan Algoritma Extreme Learning Machine (ELM). Optimasi Sistem Industri, 11(1), pp.187-192.

HILL, T., CONNOR, M.O. \& REMUS, W., 1996. Neural Network Models for Time Series Forecasts. Management Science, 42(7), pp.1082-1092.

HUANG, G. ET AL., 2015. Trends in extreme learning machines: A review. Neural Networks, 61, pp.32-48. Available at: http://dx.doi.org/10.1016/j.neunet.2014.10.001

HUANG, G.-B., ZHU, Q.-Y. \& SIEW, C.-K., 2004.
Extreme learning machine: a new learning scheme of feed forward neural networks. 2004 IEEE International Joint Conference on Neural Networks (IEEE Cat. No.04CH37541), 2, pp.25-29.

HUANG, G. BIN, ZHU, Q.Y. \& SIEW, C.K., 2006. Extreme learning machine: Theory and applications. Neurocomputing, 70(1-3), pp.489-501.

INDONESIA, B., 2017. Laporan Inflasi. Available at:

http://www.bi.go.id/id/moneter/inflasi/data/De fault.aspx.

NAFI'IYAH, N., 2016. Perbandingan Regresi Linear , Backpropagation Dan Fuzzy Mamdani Dalam Prediksi Harga Emas. Seminar Nasional Inovasi dan Aplikasi Teknologi di Industri, pp.291-296.

SARI, N.R., MAHMUDY, W.F., WIBAWA, A.P., ET AL., 2017. Enabling External Factors for Inflation Rate Forecasting using Fuzzy Neural System. International Journal of Electrical and Computer Engineering (IJECE), 7(5), pp.2746-2756.

SARI, N.R., MAHMUDY, W.F. \& WIBAWA, A.P., 2016. Backpropagation on Neural Network Method for Inflation Rate Forecasting in Indonesia. International Journal Advance Soft Computing Application, 8(3).

SARI, N.R., MAHMUDY, W.F. \& WIBAWA, A.P., 2017. The Effectiveness of Hybrid Backpropagation Neural Network Model and TSK Fuzzy Inference System for Inflation Forecasting. Journal of Telecommunication, Electronic and Computer Engineering, 9(2), pp.111-117.

SHETA, A.F., AHMED, S.E.M. \& FARIS, H., 2015. A Comparison between Regression, Artificial Neural Networks and Support Vector Machines for Predicting Stock Market Index. International Journal of Advanced Research in Artificial Intelligence, 4(7), pp.55-63. Available http://thesai.org/Publications/ViewPaper?Volu me $=4 \&$ Issue $=7 \&$ Code $=i j a r a i \&$ SerialNo $=10$.

SUGIANTO, N.A., CHOLISSODIN, I. \& WIDODO, A.W., 2018. Klasifikasi Keminatan Menggunakan Algoritme Extreme Learning Machine dan Particle Swarm Optimization untuk Seleksi Fitur ( Studi Kasus: Program Studi Teknik Informatika FILKOM UB ). Jurnal Pengembangan Teknologi Informasi dan Ilmu Komputer, 2(5), pp.1856-1865.

TIWARI, M., ADAMOWSKI, J. \& ADAMOWSKI, K., 2016. Water demand forecasting using extreme learning machines. Journal of Water and Land Development, 28(1).

UTARI, G.A.D., ARIMURTI, T. \& KURNIATI, I.N., 2012. Pertumbuhan Kredit Optimal. Buletin Ekonomi dan Perbankan, pp.3-36. 
186 Jurnal Teknologi Informasi dan Ilmu Komputer (JTIIK), Vol. 6, No. 2, April 2019, hlm. 179-186

WERBOS, P.J., 1990. Backpropagation Through Time - What It Does and How to Do It. Proceedings of the IEEE, 78(10), pp.15501560.

ZHANG, L. \& LI, J., 2012. Inflation Forecasting Using Support Vector Regression. 2012 Fourth International Symposium on Information Science and Engineering, pp.136140. Available at: http://ieeexplore.ieee.org/document/6495313/. 